\title{
Effectiveness of project PFRATH on reading performance of grade one pupils in mother tongue based-multilingual education
}

\author{
Dina M. Hubag \\ dina.hubag001@deped.gov.ph \\ Tuban Elementary School, Tuban, Santa Cruz Davao del Sur, Philippines \\ https://orcid.org/0000-0003-3155-5597 \\ Eunice F. Elona \\ eunice.elona@ deped.gov.ph \\ Tuban Elementary School, Tuban, Santa Cruz Davao del Sur, Philippines \\ https://orcid.org/0000-0003-0917-1087 \\ Mart Juffer M. Felisilda \\ martjufer.felisilda@deped.gov.ph \\ Tuban Elementary School, Tuban, Santa Cruz Davao del Sur, Philippines \\ https://orcid.org/0000-0002-4253-0398
}

\begin{abstract}
This study aims to determine the effectiveness of Project "Parents Facilitates Reading at Home" (PFRATH) to the reading performance of Grade One Pupils of Tuban Elementary School, Santa Cruz South District in Mother TongueBased Multilingual Education (MTB-MLE). The respondents of this study were the forty-six (46) Grade One Pupils whose reading proficiency was categorized as Non-decoder, Beginning and Developing level based on Early Grade Reading Assessment (EGRA) results conducted last February, 2021. This action research is a quantitative study that employed single group experimental research design using EGRA as an Assessment Tool. The researchers analyzed the data obtained in the Pre-Test and Post-Test in terms of Decoding Skill and Sentence Reading Skill of the respondents. Then, t-test was used to compare the results of tests through employing Statistical Package for the Social Sciences (SPSS) software application. The result shows that there is a significant difference between the pre-test and post test scores of the Decoding Skill and Sentence Reading Skill as evidenced by the calculated t-value and p-value. Therefore, Project PFRATH is found to be effective in improving the reading performance of the Grade One pupils. Based on the findings, the researchers made the following recommendations. The school may adopt the Project PFRATH to intensify its Reading Program. Teachers from other grade levels may utilize the Project PFRATH as reading intervention to help pupils improve their reading skill. For future researchers, a similar study on Project PFRATH may be conducted in DepEd Schools.
\end{abstract}

Keywords: Project Parents Facilitate Reading at Home (PFRATH); education; lecture skills.

\section{RESUMEN}

Este estudo tem como objetivo determinar a eficácia do Projeto "Pais Facilita a Leitura em Casa" (PFRATH) para o desempenho de leitura de Alunos da Primeira Série do Ensino Fundamental Tuban, Distrito Sul de Santa Cruz na Educação Multilíngue Baseada na Língua Materna (MTB-MLE). Os participantes deste estudo foram os quarenta e seis (46) alunos da primeira série cuja proficiência em leitura foi categorizada como não decodificadora, nível inicial e de desenvolvimento com base nos resultados da Avaliação de Leitura na Primeira Série (EGRA) realizada em fevereiro de 2021. Esta pesquisa-ação é um estudo quantitativo que empregou um projeto de pesquisa experimental de grupo único usando o EGRA como uma ferramenta de avaliação. Os pesquisadores analisaram os dados obtidos no Pré-Teste e Pós-Teste em termos de Habilidade de Decodificação e Habilidade de Leitura de Frases dos respondentes. Em seguida, o teste $\mathrm{t}$ foi utilizado para comparar os resultados dos testes por meio do software Statistical Package for the Social Sciences (SPSS). O resultado mostra que há uma diferença significativa entre os 
escores do pré-teste e do pós-teste da habilidade de decodificação e habilidade de leitura de frases, conforme evidenciado pelo valor $\mathrm{t}$ e valor $\mathrm{p}$ calculados. Portanto, o Projeto PFRATH é considerado eficaz na melhoria do desempenho de leitura dos alunos da primeira série. Com base nas descobertas, os pesquisadores fizeram as seguintes recomendações. A escola pode adotar o Projeto PFRATH para intensificar seu Programa de Leitura. Os professores de outras séries podem utilizar o Projeto PFRATH como uma intervenção de leitura para ajudar os alunos a melhorar suas habilidades de leitura. Para futuros pesquisadores, um estudo semelhante no Projeto PFRATH pode ser conduzido nas Escolas do DepEd.

Palavras-chave: Projeto Pais facilitam a leitura em casa (PFRATH); leitura; educação.

\section{RESUMO}

Este estudio tiene como objetivo determinar la efectividad del Proyecto "Los padres facilitan la lectura en casa" (PFRATH) para el desempeño en lectura de los alumnos de primer grado de la escuela primaria Tuban, distrito sur de Santa Cruz en educación multilingüe basada en la lengua materna (MTB-MLE). Los encuestados de este estudio fueron los cuarenta y seis (46) alumnos de primer grado cuya competencia en lectura se clasificó como nivel no decodificador, principiante y en desarrollo según los resultados de la evaluación de lectura de primer grado (EGRA, por sus siglas en inglés) realizados el pasado febrero de 2021. Esta investigación de acción es un estudio cuantitativo que empleó un diseño de investigación experimental de un solo grupo utilizando EGRA como una herramienta de evaluación. Los investigadores analizaron los datos obtenidos en la prueba previa y posterior en términos de habilidad de decodificación y habilidad de lectura de oraciones de los encuestados. Luego, se utilizó la prueba t para comparar los resultados de las pruebas mediante el uso de la aplicación de software Statistical Package for the Social Sciences (SPSS). El resultado muestra que hay una diferencia significativa entre las puntuaciones de la prueba previa y posterior de la habilidad de decodificación y la habilidad de lectura de oraciones, como lo demuestran el valor t y el valor $\mathrm{p}$ calculados. Por lo tanto, el Proyecto PFRATH resulta eficaz para mejorar el rendimiento en lectura de los alumnos de primer grado. Con base en los hallazgos, los investigadores hicieron las siguientes recomendaciones. La escuela puede adoptar el Proyecto PFRATH para intensificar su Programa de Lectura. Los maestros de otros niveles de grado pueden utilizar el Proyecto PFRATH como intervención de lectura para ayudar a los alumnos a mejorar su habilidad de lectura. Para los futuros investigadores, se puede realizar un estudio similar sobre el Proyecto PFRATH en las Escuelas DepEd.

Palabras clave: Proyecto Los padres facilitan la lectura en casa (PFRATH), lectura, educación.

\section{INTRODUCTION}

An increasing number of non-readers in school is one of the crucial problems faced by most school administrators and teachers in the Department of Education this time of COVID-19 pandemic. Administrators and teachers always find ways and means to address this problem.

Tuban Elementary School also faced this challenging situation where reading performance of pupils especially in the primary levels is at risk. Teachers found it difficult to employ effective reading strategies and teach children how to read using distance learning approach, where the school adopt modular distance learning. The recently conducted Pre-test for Early Grade Reading Assessment in Grade One pupils of Tuban Elementary School, Santa Cruz, South District, Division of Davao del Sur last February, 2021, showed pupils' low performance in Reading.

To address this problem, Teacher-researchers of the said school proposed an action research to improve the reading performance of pupils through Project "Parents Facilitate Reading at Home" (PFRATH), a reading intervention that involves active participation of parents. The researchers are interested to examine its effectiveness in improving the reading performance of Grade One Pupils in Mother Tongue Based-Multilingual Education (MTB-MLE).

\section{Statement of the Problem}


The focus of this action research study was to determine the effectiveness of project PFRATH on the Reading performance of Grade One pupils in MTB-MLE. Thus, the researchers sought to answer the following questions:

1. What is the mean of Pre-test result of Grade One pupils in MTB-MLE using the Early Grade Reading Assessment (EGRA) in terms of:

- Decoding Skill Assessment

- Sentence Reading?

2. What is the mean of Post-test result of Grade One pupils in MTB-MLE using the Early Grade Reading Assessment (EGRA) after administering the Project PFRATH in terms of:

- Decoding Skill Assessment

- Sentence Reading?

3. Is there a significant difference between the Pre-Test and Post-Test Results of Grade One pupils in MTB-MLE using the EGRA Assessment in terms of:

- Decoding Skill Assessment

4. Sentence Reading?Is project PFRATH effective on Reading Performance of Grade One pupils in MTB-MLE?

\section{THEORETICAL FOUNDATION}

The foundation of this action research was anchored on the Schema Theory of Rumelhart (1980) as cited by Shen (2008) and the Theory of Conservation and Reading Readiness of Piaget (1950) as cited by Alsaadat (2020). These theories both believed that understanding a text is an interactive process between the readers' background knowledge and the text. It is certainly helpful to enhance the pupils' prior knowledge and to guide them to connect their existing knowledge to the modern world (Shen, 2008). Teachers and parents affects the child positively or negatively that depends on their methods and approaches (Alsaadat, 2020).

\section{METHODOLOGICAL PROCEDURES}

This chapter presented the design, respondents and sampling, data collection procedure, and data analysis.

\subsection{Research Design}

This action research is a quantitative study that employed single group experimental research design using EGRA as an Assessment Tool. The researchers analyzed the data obtained in the Pre-Test and Post-Test in terms of Decoding Skill and Sentence Reading Skill of the respondents. Then, t-test was used to compare the results of tests through employing Statistical Package for the Social Sciences (SPSS) software application.

\subsection{Respondents and Sampling}

Forty-six (46) Grade One pupils of Tuban Elementary School who were enrolled this school year 2020-2021 were chosen to be the participants of the study. Through purposive sampling these pupils were taken from the Non-decoder, Beginning and Developing level based on the results of EGRA assessment conducted in February 2021.

\subsection{Data Gathering Procedure}

In order to gather the data needed and to explore the effectiveness of the intervention, the following procedures were used: 
A letter was sent to ask permission on the conduct of the study through the School Principal, District Research Committee and the Division Research Committee. After the approval of the study, proper coordination with the parents of the identified pupil respondents was done by the researchers.

The researchers utilized the results of the recently conducted EGRA last February, 2021. Out of 121 pupils in Grade One there were 46 pupils who belonged to Non-decoder, Beginning and Developing level. These forty-six (46) pupils were identified to be the subjects of the study. The researchers conducted Pre-assessment to verify the present reading status of the selected participants. The parents were informed about their children's reading status and invited them for an orientation about the intervention project.

The researchers then monitored closely the parents through home visitation observing safety health protocols, or through direct or text messages and mobile calls.

Post-Tests were personally conducted by the researchers using the same reading assessment tool given during the Pre-test, with a permission granted by the School Principal, Barangay and IATF.

The researchers gathered all the data and tabulated the results.

\subsection{Data Analysis}

Statistical Package for the Social Sciences (SPSS) software application was used to treat the acquired data.

\section{RESULTS AND DISCUSSION}

In this section, the findings of a study named "Effectiveness of Project PFRATH on Reading Performance of Grade One Pupils in Mother Tongue Based-Multilingual Education" are presented.

\subsection{Table 1. Pre-Test Results in Terms of Decoding Skill}

\begin{tabular}{lll}
\hline Score & Frequency & Description \\
10 & 0 & Advance \\
$9-8$ & 0 & Proficient \\
$7-6$ & 0 & Approaching Proficiency \\
$5-4$ & 12 & Developing \\
$3-2$ & 12 & Beginning \\
$1-0$ & 22 & Non Decoder \\
\hline
\end{tabular}

Mean $=2.33($ Beginning $)$

$\mathrm{SD}=2.16$

Presented in Table 1 are the results of pre-test in decoding skill of grade one learners. As indicated, there were no pupils identified to be in Advance, Proficient and Approaching Proficiency category. There were 12 pupils in Developing category, 12 pupils in Beginning category and 22 pupils in Non Decoder category. The over-all mean obtained is 2.33 with a standard deviation of 2.16, which is categorized as Developing.

\subsection{Table 2. Pre-Test Results in Terms of Sentence Reading Skill}

\begin{tabular}{lc}
\hline Score & Frequency \\
\hline Sapienza: International Journal of Interdisciplinary Studies | Vol. 2 | n. 3 & Jul-Set | 2021 | e-ISSN: 2675-9780
\end{tabular}




\begin{tabular}{lll}
5 & 0 & Advance \\
4 & 0 & Proficient \\
3 & 0 & Approaching Proficiency \\
2 & 5 & Developing \\
1 & 0 & Beginning \\
0 & 41 & Non-Reader \\
\hline
\end{tabular}

Mean $=0.37$ (Non-Reader)

$\mathrm{SD}=1.10$

Presented in Table 2 are the results of pre-test in sentence reading skill of grade one learners. As indicated, there were no pupils identified to be in Advance, Proficient and Approaching Proficiency category. There were 5 pupils in Developing category, no pupil in Beginning category and 41 pupils who are in the Non-Reader category. The over-all mean obtained is 0.37 with a standard deviation of 1.10 , which is categorized as Developing.

\subsection{Table 3. Post Test Results in Terms of Decoding Skill}

\begin{tabular}{lll}
\hline Score & Frequency & Description \\
10 & 5 & Advance \\
$9-8$ & 9 & Proficient \\
$7-6$ & 23 & Approaching Proficiency \\
$5-4$ & 9 & Developing \\
$3-2$ & 0 & Beginning \\
$1-0$ & 0 & Non Decoder \\
\hline
\end{tabular}

Mean $=6.96$ (Approaching Proficiency)

$\mathrm{SD}=1.67$

Presented in Table 3 are the results of post-test in decoding skill of grade one learners. As indicated, there were 5 pupils identified to be in Advance category, 9 pupils in Proficient, 23 pupils in Approaching Proficiency and 9 pupils in Developing category. There were no pupils identified in Beginning and Non-Decoder category. The over-all mean obtained is 6.96 with a standard deviation of 1.67, which is categorized as Approaching Proficiency.

\subsection{Table 4. Post Test Results in Terms of Sentence Reading Skill}

\begin{tabular}{lll}
\hline Score & Frequency & Description \\
5 & 6 & Advance \\
4 & 2 & Proficient \\
3 & 13 & Approaching Proficiency \\
2 & 21 & Developing \\
1 & 4 & Beginning \\
0 & 0 & Non-Reader \\
\hline
\end{tabular}

Mean $=2.67$ (Developing)

$\mathrm{SD}=1.14$

Presented in Table 4 are the results of post-test in sentence reading skill of grade one learners. As indicated, there were 6 pupils in Advance category, 2 pupils in Proficient, 13 pupils in Approaching Proficiency, 21 pupils in Developing, and 4 pupils in Beginning. There were no 
pupils identified in Non-Reader category. The over-all mean obtained is 2.67 with a standard deviation of 1.14, which is categorized as Developing.

\subsection{Table 5. Comparison on the Decoding Skills of Grade One Pupils}

\begin{tabular}{lllllll}
\hline & mean & sd & $\begin{array}{l}\text { p-value } \\
\text { (at } 0.05 \text { level of } \\
\text { significance) }\end{array}$ & df & t-value & $\begin{array}{l}\text { t-critical } \\
\text { value (2 tail) }\end{array}$ \\
PRETEST & 2.33 & 2.16 & & & & \\
POST TEST & 6.96 & 1.67 & 0.000 & 45 & 15.8477 & 2.0141 \\
\hline
\end{tabular}

$\mathrm{n}=46$

Table 5 presents the comparison of the pre-test and post-test data in terms of the Decoding Skills of Grade One Pupils. The pretest result has a mean of 2.33 with standard deviation of 2.16 which is described as Beginning Level while the post test result has a mean of 6.96 with a standard deviation of 1.67 which is described as Approaching Proficiency Level based on the EGRA Rating Scale.

The data shows that there is a significant difference between the pretest and post test results of the Grade One Pupils in their decoding skills as supported by the p value of 0.000 which is less than the level of significance at 0.05 , and with a calculated t-value of 15.85 which is greater than the t-critical value of 2.01 .

It implies that after utilizing the PFRATH as a reading intervention, there is a significant improvement in the reading performance of Grade One Pupils in terms of decoding skills, from Beginning level to Approaching Proficiency level.

\subsection{Table 6. Comparison on the Sentence Reading Skills of Grade One Pupils}

\begin{tabular}{lcclccc}
\hline & mean & sd & $\begin{array}{l}\text { p-value } \\
\text { (at } 0.05 \text { level of } \\
\text { significance) }\end{array}$ & df & t-value & $\begin{array}{l}\text { t- critical } \\
\text { value (2 tail) }\end{array}$ \\
PRETEST & 0.37 & 1.10 & & & \\
POST TEST & 2.67 & 1.14 & 0.000 & 45 & 14.8657 & 2.0141 \\
\hline $\mathrm{n}=46$ & & & & &
\end{tabular}

Table 6 presents the comparison of the pre-test and post-test data in terms of the Sentence Reading Skills of Grade One Pupils. The pretest result has a mean of 0.37 with standard deviation of 1.10 which is described as Non-Reader Level while the post test result has a mean of 2.67 with a standard deviation of 1.14 which is described as Developing Level based on the EGRA Rating Scale.

The data shows that there is a significant difference between the pretest and post test results of the grade one pupils in their sentence reading skills as supported by the p-value of 0.000 which is less than the level of significance at 0.05 , and with a calculated t-value of 14.87 which is greater than the t-critical value of 2.01 .

It implies that after utilizing the PFRATH as a reading intervention, there is a significant improvement in the reading performance of Grade One Pupils in terms of sentence reading skills, from Non-Reader level to Developing level. 


\section{CONCLUSION}

Based on the findings, the Project "Parents Facilitate Reading At Home" (PFRATH) is therefore proven to be effective in improving the reading performance of Forty-six (46) Grade One Pupils of Tuban Elementary School who were identified as Non-decoders, Beginning Readers and Developing Readers in the Mother Tongue Based-Multilingual Education (MTBMLE) who were enrolled this school year 2020-2021 as evidenced by the significance of the differences of the means between the Pre-Test and Post-Test conducted.

\section{PLAN OF ACTION}

The researchers have decided to disseminate the findings of the study to their colleagues through School Learning Action Cell (SLAC) Session. Teachers will be oriented on the utilization of Project PFRATH as an intervention to their pupils with low performance in reading. Constant monitoring and evaluation will be conducted to teachers and parents after months of implementation.

\section{REFERENCES}

Cassidy, J. Garcia, R., Tejeda-Delgado, C., Garrett, S.D., Martinez-Garcia, C.\& Hinojosa

R.V. (2004). A learner -centered family literacy project for Latino parents and caregivers. International Reading Association, (478-488).

Darch, C., Miao, Y., \& Shippen, P. (2004). A model for involving parents of children with Learning and behavior problems in the school. Preventing School Failure, 48(3), (24-34).

Darling, S. (2005). Strategies for engaging parents in home support of reading acquisition. International Reading Association, (476-479).

Hindin, A, \& Paratore, J.R. (2007). Supporting young children's literacy learning through home- School partnerships: The effectiveness of a home repeated-reading intervention. Journal of Literacy Research, 39(3), (307-333).

Roberts, Kathleen P. (1976) “The Reading Teacher” A Journal Article Vol. 30, No. 3 (Dec., 1976), pp. 246-250 (5 pages) Published By: International Literacy Association

Tekin, Ali (2011) "Parent Involvement Revisited: Background, Theories and Models" A Journal Volume 10, International Journal of Applied Educational Studies

Xue, Yang (2019) “The Use of Schema Theory in the Teaching of Reading Comprehension” International Journal of Liberal Arts of Social Sciences, pp. 60. 